\title{
RADIOCARBON DATES FROM THE MUSSAU ISLANDS AND THE LAPITA COLONIZATION OF THE SOUTHWESTERN PACIFIC
}

\author{
$\mathrm{P}$ V KIRCH and T L HUNT
}

The Burke Museum, University of Washington Seattle, Washington 98195

Three decades of archaeological excavations in Melanesia and Western Polynesia have led to a consensus among Oceanic prehistorians that the initial human colonization of the southwestern Pacific (east of the Solomons) was effected by populations of the Lapita Cultural Complex (Green, 1979; Kirch, 1982, 1984; Allen, 1984; Spriggs, 1984). Although the western Melanesian islands of New Guinea, the Bismarck Archipelago, and possibly the Solomon Islands were settled in the late Pleistocene by small huntergatherer populations (Downie \& White, 1979; Specht, Lilley \& Normu, 1981; Groube et al, 1986), discovery and occupation by humans of the more remote island chains to the east required sophisticated voyaging and colonization strategies. That the Austronesian-speaking Lapita people possessed long-distance voyaging craft is suggested both by lexical reconstructions, and by the archaeological evidence of long-distance transport of obsidian and other exotic materials over distances of up to $3700 \mathrm{~km}$ (Ambrose \& Green, 1972; Best, 1987). Lapita sites are marked by a distinctive complex of dentate-stamped earthenware ceramics, and associated shell, bone, and stone artifacts. Sites yielding such assemblages have been recorded between the Bismarck Archipelago in the west, through Melanesia, and as far east as Samoa and Tonga, a straight-line distance of ca $4500 \mathrm{~km}$.

Establishing a radiometric chronology for the Lapita Cultural Complex has been a matter of substantial concern for Oceanic archaeologists. Green (1979, p 32-34, Table 2.1) synthesized the available ${ }^{14} \mathrm{C}$ corpus as of the late $1970 \mathrm{~s}$ and, on the basis of 26 "reliable" dates, concluded that "Lapita sites as a cultural horizon date from between 1600 and 500 B.C." However, Green was unable to specify more precisely the timing of the Lapita dispersal from the Bismarcks eastwards into the central Pacific. Recently, Anson (1986, p 164) relied upon an anomalously early ${ }^{14} \mathrm{C}$ date from the Mussau ECA site to argue that there had been a phase of Lapita cultural development in the Bismarck Archipelago "which predates the Lapita expansion eastward into the Pacific by some centuries." (This date, reported by Bafmatuk, Egloff \& Kaiku (1980), was one of two determinations from a single "oven" feature. The wide separation of ages, $3900 \pm$ $260 \mathrm{BP}(\mathrm{GX}-5499)$ and $3030 \pm 180 \mathrm{BP}(\mathrm{GX}-5498)$, in two samples from a single presumed cultural feature makes these dates questionable, in our view.) Establishing a rate for Lapita dispersal is a significant research problem for, as Clark and Terrell (1978) and Diamond (1977) have suggested, the movement of voyager-colonists across the southwestern Pacific may be among the most rapid dispersal events in human prehistory. Diamond 
(1977, p 258) has gone so far as to draw a biogeographic comparison between Lapita populations and certain "supertramp" species of birds.

In 1985-86, the senior author directed a major excavation program at four Lapita sites in the Mussau (St Matthias) Islands, on the northern periphery of the Bismark Archipelago (Kirch, 1987). Our purpose in this paper is to present a corpus of $20{ }^{14} \mathrm{C}$ ages from these sites, the first substantial set of radiometric dates for the Lapita occupation of the Bismarcks, and the largest single suite of ${ }^{14} \mathrm{C}$ ages for any Lapita locality in the Pacific. These ages are then analyzed within the context of the entire corpus of 78 available radiocarbon dates from all known Lapita sites, and a preliminary assessment is offered of the rate of Lapita dispersal through and colonization of the southwestern Pacific.

\section{THE RADIOCARBON SEQUENCE FROM MUSSAU}

The 20 radiocarbon samples from Mussau ( $\left(149^{\circ} 37^{\prime} \mathrm{E}, 1^{\circ} 26^{\prime} \mathrm{S}\right)$ were excavated from four sites, all of which yielded classic dentate-stamped as well as incised Lapita ceramics (Kirch, 1987). Sites ECA and ECB are open midden deposits in low-lying calcareous Holocene sediments on Eloaua Island, while Site EHB is an open midden in similar terrain on Emananus Island. Both Eloaua and Emananus Islands form part of an atoll lying immediately SW of the main island of Mussau. The EKQ site is a coastal rock shelter (situated in uplifted limestone terrain) with $2.5 \mathrm{~m}$ of stratified occupation deposits in the Tanaliu area of Mussau Island. The samples include marine shells deposited in sites as dietary refuse (Tridacna gigas and Pycnodonta sp), wood charcoal, noncarbonized anaerobically-preserved wood, and noncarbonized coconut endocarp. All samples selected for radiocarbon analysis were collected from secure stratigraphic contexts in direct association with Lapita pottery and other cultural materials.

${ }^{14} \mathrm{C}$ measurements were performed by the Australian National University Radiocarbon Dating Research Laboratory (15 samples) and by Beta Analytic, Inc (5 samples). The ANU laboratory pretreated marine shell samples by removal of exterior surfaces with a dental drill, whereas the Beta Analytic laboratory cleaned outer shell surfaces with dilute acid. In all cases, the ${ }^{13} \mathrm{C} /{ }^{12} \mathrm{C}$ ratio was measured to establish a ${ }^{13} \mathrm{C}$ adjusted, "conventional ${ }^{14} \mathrm{C}$ age" (Stuiver \& Polach, 1977). Corrections for specific ${ }^{14} \mathrm{C}$ activity, and for the marine reservoir effect taking into account regional ocean variation (Delta-R estimates), as well as calibration for secular effects, were made following the recent work of Stuiver, Pearson and Braziunas (1986) for marine samples, and of Stuiver and Becker (1986) for terrestrial samples. For calibration of Lapita marine samples, we have used a Delta-R value of $100 \pm 24$. This value is the weighted average of Delta- $R$ values from Eniwetok, Hawaii, and the Society Islands (Stuiver, Pearson \& Braziunas, 1986, Table 1). We suggest that as a first approximation, this pooled value best represents a Delta-R value for the tropical central Pacific. Calibrations and probability estimates were made using a revised FORTRAN microcomputer program provided to the authors by $\mathrm{M}$ Stuiver and $\mathrm{P}$ Reimer ( $c f$, Stuiver \& Reimer, 1986). Details of all 20 samples are presented 
CAL YEARS BC

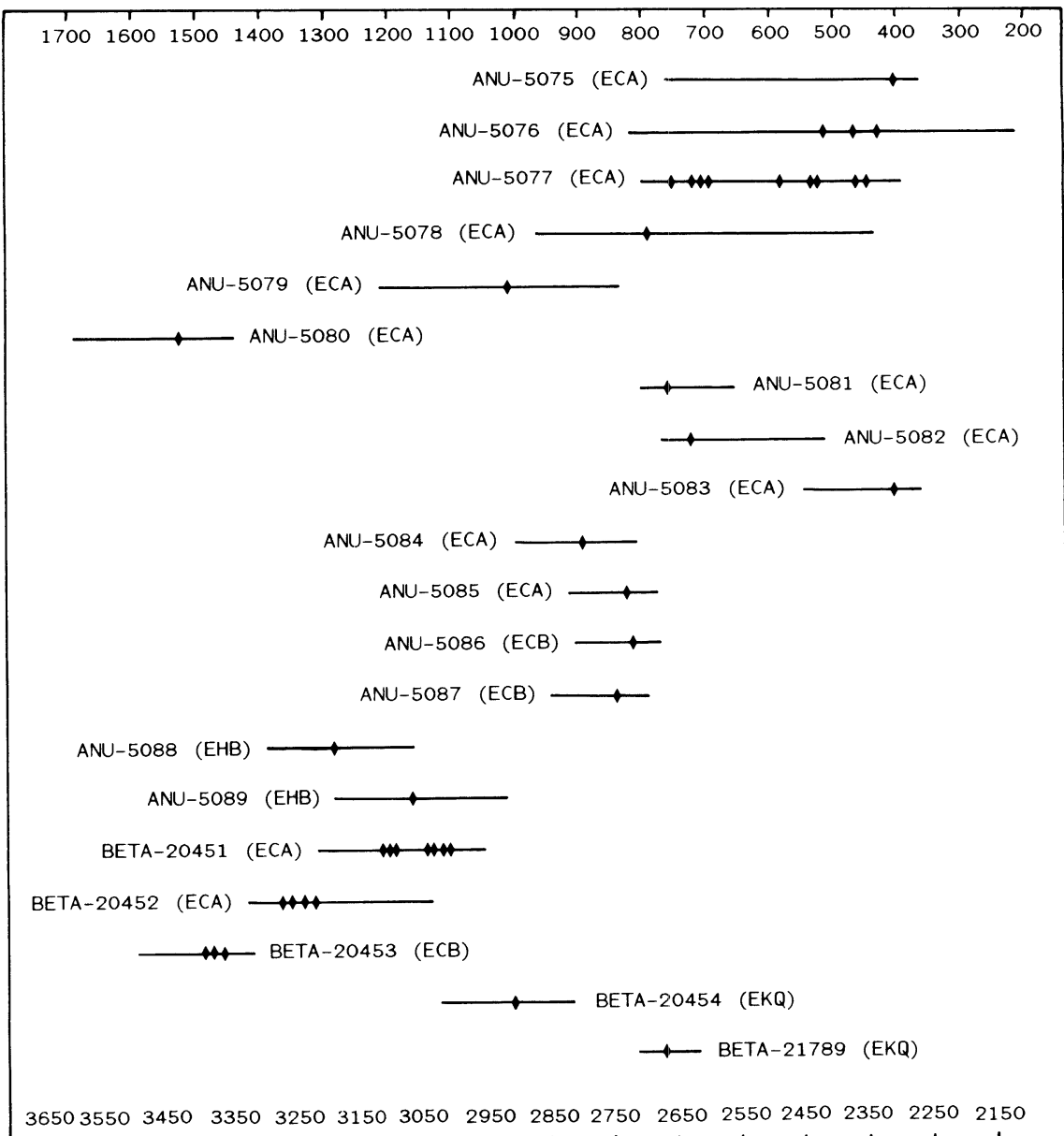

CAL YEARS BP

Fig 1. Calibrated age ranges (at $1 \sigma$ ) for ${ }^{14} \mathrm{C}$ dates from the Mussau Islands Lapita sites. Tick marks indicate intercept points.

at the end of this paper. Figure 1 displays the calibrated age (cal BC and BP) and age ranges for all samples at one standard deviation.

This large suite of ${ }^{14} \mathrm{C}$ ages provides a local chronologic sequence for the Lapita occupation of the Mussau Islands that is generally consistent with internal site stratigraphy. The large ECA site was first settled ca 1500 $\mathrm{BC}$, and occupation persisted until ca $500 \mathrm{BC}$. The GX-5944 date of $3900 \pm$ $260 \mathrm{BP}$, reported by Bafmatuf, Egloff and Kaiku (1980) from ECA is clearly anomalous in the context of this expanded sample of ${ }^{14} \mathrm{C}$ ages, and confirms our view based on archaeological considerations, that the sample does not date cultural materials. The ECB site on Eloaua was first occupied about 
the same time as ECA, ca $1500 \mathrm{BC}$, and was abandoned probably ca $1000 \mathrm{BC}$. The two dates from the EHB site on Emananus suggest that it may have been occupied for a relatively short period between ca 1500-1200 BC. The ages of the two samples from the EKQ rock shelter are inverted with regard to stratigraphic position, but overlap at two standard deviations. The basal levels of this site were evidently occupied between ca 1000-800 BC.

The Mussau radiocarbon suite supports Green's (1979) earlier conclusion that the Lapita horizon in Melanesia spans the period from ca $1600-$ 500 BC. Contrary to Anson's hypothesis (1986), there is no evidence for a period of Lapita development in the Bismarck Archipelago substantially antedating the dispersal of Lapita populations eastwards into island Melanesia and Polynesia.

\section{RADIOMETRIC EVIDENCE FOR THE LAPITA DISPERSAL}

The Mussau excavations, along with other archaeological work on Lapita sites throughout the Pacific, have now resulted in a corpus of $78{ }^{14} \mathrm{C}$ age determinations, providing sufficient empirical data to attempt an assessment of the rate of Lapita dispersal over the $4500 \mathrm{~km}$ region from the Bismarcks to Samoa and Tonga. Kirch and Hunt (in press) provide a compilation of all ${ }^{14} \mathrm{C}$ dates presently available from Lapita sites, including calibrations for ocean reservoir effect and secular variation, following the methods of Stuiver, Pearson and Braziunas (1986) and Stuiver and Becker (1986).

In Figure 2, we have plotted this Lapita radiocarbon corpus as four

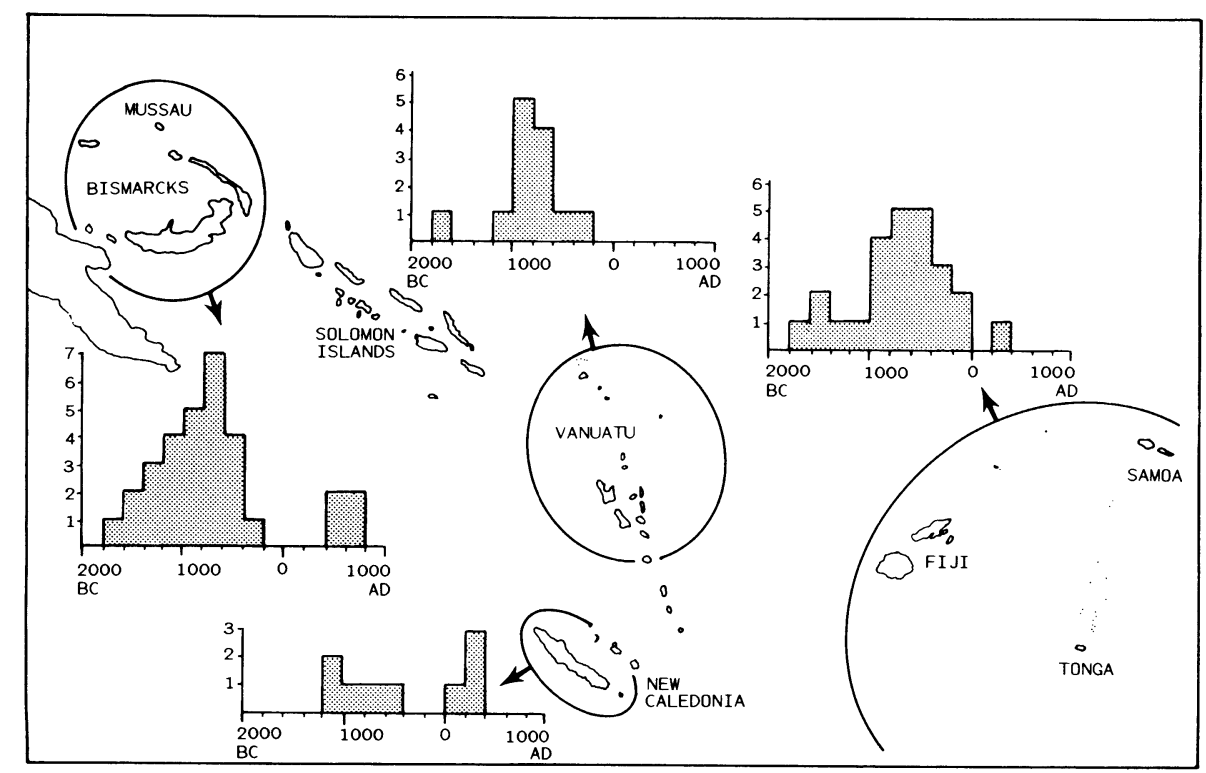

Fig 2. Histograms of calibrated $\mathrm{BC}$ age intercepts at 200 -yr intervals for ${ }^{14} \mathrm{C}$ dates from Lapita sites in four geographic regions. See text for further discussion. 
sets of histograms, each set representing a group of sites from a geographic locality throughout an archaeologically attested range of Lapita dispersal. Histograms were constructed by plotting the calibrated $\mathrm{BC}$ age intercepts according to 200-yr intervals (where there is more than one intercept for a sample, we plotted the intercept within the highest range of probability). The frequency distributions of radiocarbon ages from each of these geographic regions are remarkably consistent in their modal cal $\mathrm{BC}$ ages, and no clear age-distance progression is evident. In particular, the date frequency distributions for the two geographic localities most widely separated in space (the Bismarcks and the Fiji-Western Polynesia group) display nearly identical ranges and the same modes. To further test whether any agedistance correlation could be derived from these radiometric data, we regressed the calibrated BP ages against distance from Aitape, New Guinea, the most westerly known Lapita locality. The simple correlation $(R)$ value between cal BP age and $\mathrm{km}$ distance is .0368 , indicating no significant relationship.

From these data, we hypothesize that the rate of Lapita dispersal through and initial colonization of the southwestern Pacific was sufficiently rapid so as to be undetectable within the statistical uncertainty range of radiocarbon dating and of archaeological sampling error (ie, the problem of archaeologically locating the earliest sites within any particular island group). Lapita populations evidently moved into this vast island region over a period of not more than ca 300 years, which would amount to an average rate of ca $150 \mathrm{~km}$ per decade. Based on the ${ }^{14} \mathrm{C}$ data presented above, the rate of spread could have been even more rapid. Even conservatively estimated at 300 years, however, the speed of this Neolithic dispersal is highlighted by comparison with the radiometrically documented diffusion of early agriculture from the Near East across Europe (Ammerman \& CavalliSforza, 1984, p 50-62). The European agricultural diffusion occurred at the rate of ca $1000 \mathrm{~km}$ per millennium. Thus, the Lapita dispersal in Oceania was at least 15 times more rapid than the spread of early farming through Europe. To some extent, the rapidity of Lapita expansion may be attributed to its over-water nature. Nonetheless, it stands as a remarkable event in world prehistory.

\section{ACKNOWLEDGMENTS}

We thank Henry Polach and John Head of the ANU Radiocarbon Dating Research Laboratory for their analysis of 15 samples from Mussau. The 1985 samples were submitted by Chris Gosden, ANU, for the Lapita Homeland Project. Minze Stuiver and Paula Reimer of the Quaternary Research Center (University of Washington) provided us with updated versions of their microcomputer calibration program, and have been generous with their time in answering our queries. Tom Braziunas, also of the QRC, discussed the problems of developing a Delta- $R$ value for the tropical Pacific. The research results reported here have been supported by grants from the National Geographic Society (3304-86) and the National Science Foundation (BNS-8615147). 


\section{Eloaua Island series}

\section{ANU-5075. Eloaua Island}

Wood charcoal from Site ECA, Area B, Unit W200N149, Level 7, Zone C1. Assoc with waterlogged, anaerobically-preserved remains of Lapita stilt-house occupation. Cal BC 761 (406) 364 at $1 \sigma$; cal BP 2710 (2355) 2313 at $1 \sigma$.

\section{ANU-5076. Eloaua Island}

$2430 \pm 230$

Wood charcoal from Site ECA, Area B, Unit W200N151, Level 8, Zone C1. Assoc with waterlogged, anaerobically-preserved remains of Lapita stilt-house occupation. Cal BC $820(516,467,433) 212$ at $1 \sigma$; cal BP $2769(2465,2416,2382) 2161$ at $1 \sigma$.

\section{ANU-5077. Eloaua Island}

$2450 \pm 160$

Wood charcoal from Site ECA, Area B, Unit W201N151, Level 9, Zone $\mathrm{C} 1$. Assoc with waterlogged, anaerobically-preserved remains of Lapita stilt-house occupation. Cal BC $800(752,720,708,695,586,585$, $538,533,521,463,447) 390$ at $1 \sigma$; cal BP $2749(2701,2669,2657,2644$, $2535,2534,2487,2482,2470,2412,2396) 2339$ at $1 \sigma$.

\section{ANU-5078. Eloaua Island}

$2600 \pm 160$

Wood charcoal from Site ECA, Area B, Units W199-W200N150, Level 18 , Zones C2-3. Assoc with waterlogged, anaerobically-preserved remains of Lapita stilt-house occupation. Cal BC 967 (797) 437 at $1 \sigma$; cal BP 2916 (2746) 2386 at $1 \sigma$.

\section{ANU-5079. Eloaua Island}

$2840 \pm 120$

Wood charcoal from Site ECA, Area B, Unit W200N150, Levels 12 13, Zone C1. Assoc with waterlogged, anaerobically-preserved remains of Lapita stilt-house occupation. Cal BC 1213 (1010) 836 at $1 \sigma$; cal BP 3162 (2959) 2785 at $1 \sigma$.

\section{ANU-5080. Eloaua Island}

$$
\begin{array}{r}
\mathbf{3 2 6 0} \pm \mathbf{9 0} \\
\delta^{13} C=-24.0 \% 0
\end{array}
$$

Wood charcoal from Site ECA, Transect Unit 9, Level 6, assoc with Lapita pottery and other cultural materials in organically-enriched midden of calcareous sand matrix. Cal BC 1687 (1526) 1441 at $1 \sigma$; cal BP 3636 (3475) 3390 at $1 \sigma$. 


\section{ANU-5081. Eloaua Island}

$$
\mathbf{3 0 1 0} \pm \mathbf{8 0}
$$

$\delta^{13} C=0.0 \%$

Marine shell (Tridacna gigas) from Site ECA, Area B, Unit W200N151, Level 11, Zone C3. Shell was culturally deposited; assoc with stilt-house occupation. Cal BC 803 (761) 658 at $1 \sigma$; cal BP 2752 (2710) 2607 at $1 \sigma$.

\section{ANU-5082. Eloaua Island}

$$
\begin{array}{r}
2950 \pm 80 \\
\delta^{I 3} C=0.0 \%
\end{array}
$$

Marine shell (Pycnodonta sp) from Site ECA, Area B, Unit W201N149, Level 12, Zone C3. Culturally deposited midden shell assoc with stilt-house occupation. Cal BC 772 (723) 514 at $1 \sigma$; cal BP 2721 (2672) 2463 at $1 \sigma$.

\section{ANU-5083. Eloaua Island}

$$
\mathbf{2 8 1 0} \pm \mathbf{8 0}
$$

Marine shell (Pycnodonta sp) from Site ECA, Area B, Unit W200N149, Level 3, Zone B1. From calcareous sand midden overlying waterlogged stilt-house occupation zone. Cal BC 548 (406) 364 at 1 $\sigma$; cal BP 2497 (2355) 2313 at $1 \sigma$.

\section{ANU-5084. Eloaua Island}

$3190 \pm 80$

Marine shell (Tridacna gigas) from Site ECA, Area A, Unit W228N102, Level 3. Assoc with Lapita plainware ceramics. Cal BC 1001 (898) 809 at $1 \sigma$; cal BP 2950 (2847) 2758 at $1 \sigma$.

\section{ANU-5085. Eloaua Island}

$$
\mathbf{3 1 3 0} \pm \mathbf{8 0}
$$

Marine shell (Pycnodonta sp) from Site ECA, Area A, Unit W229N100, Level 9. Assoc with Lapita plainware ceramics. Cal BC 919 (826) 779 at $1 \sigma$; cal BP $2868(2775) 2728$ at $1 \sigma$.

\section{ANU-5086. Eloaua Island}

$3120 \pm 80$

Marine shell (Pycnodonta sp) from Site ECB, Unit 1, Level 1. From ceramic-bearing cultural deposit in calcareous sand matrix. Cal BC 909 (818) 774 at $1 \sigma$; cal BP 2858 (2767) 2723 at $1 \sigma$.

\section{ANU-5087. Eloaua Island}

$$
\begin{array}{r}
\mathbf{3 1 5 0} \pm \mathbf{8 0} \\
\delta^{13} \mathrm{C}=0.0 \%
\end{array}
$$

Marine shell (Pycnodonta sp) from Site ECB, Unit 1, Level 2. From ceramic-bearing cultural deposit in calcareous sand matrix. Cal BC 949 (846) 790 at $1 \sigma ;$ cal BP 2898 (2795) 2739 at $1 \sigma$.

\section{Beta-20451. Eloaua Island}

$$
\begin{array}{r}
2950 \pm 70 \\
\delta^{13} C=-24.0 \% 0
\end{array}
$$

Anaerobically-preserved, noncarbonized coconut (Cocos nucifera) endocarp from Site ECA, Transect Unit 18, Level 9. From deposit of pre- 
served domesticated plant remains, assoc with dentate-stamped Lapita ceramics. Cal BC $1315(1212,1202,1192,1141,1132,1118,1115) 1051$ at $1 \sigma$; cal BP $3264(3161,3151,3141,3090,3081,3067,3064) 3000$ at $1 \sigma$.

\section{Beta-20452. Eloaua Island}

$3050 \pm 70$

Worked wooden post (No. 30) from Site ECA, Area B, Unit W198N148, Zone C. This anaerobically-preserved post is part of a stilthouse occupation complex (see Kirch, 1987). Cal BC 1429 (1372, 1359, $1354,1337,1320) 1135$ at $1 \sigma$; cal BP $3378(3321,3308,3303,3286,3269)$ 3084 at $1 \sigma$.

\section{Beta-20453. Eloaua Island}

$$
\begin{array}{r}
\mathbf{3 2 0 0} \pm \mathbf{7 0} \\
\delta^{13} C=-24.0 \%
\end{array}
$$

Wood charcoal from Site ECB, Unit 9, Level 5 . Directly assoc with dentatestamped ceramics in organically-enriched midden, calcareous sand matrix. Cal BC $1597(1492,1478,1463) 1414$ at $1 \sigma$; cal вP $3546(3441,3427,3412)$ 3363 at $1 \sigma$.

\section{Emananus Island series}

\section{ANU-5088. Emananus Island}

$3470 \pm 90$

$\delta^{13} C=0.0 \%$

Marine shell (Tridacna gigas) from Site EHB, Unit 1, Level 9. From base of ceramic-bearing cultural deposit in calcareous sand matrix. Cal BC 1397 (1288) 1161 at $1 \sigma$; cal BP 3346 (3237) 3110 at $1 \sigma$. Directly assoc with classic dentate-stamped Lapita.

\section{ANU-5089. Emananus Island}

$3380 \pm 90$

Marine shell (Pycnodonta sp) from Site EHB, Unit 2, Level 6. From ceramic-bearing cultural deposit in calcareous sand matrix. Directly assoc with classic dentate-stamped Lapita. Cal BC 1292 (1167) 1016 at $1 \sigma$; cal BP $3241(3116) 2965$ at $1 \sigma$.

\section{Mussau Island series}

\section{Beta-20454. Mussau Island}

$3280 \pm 70$

Marine shell fragments from Site EKQ, Unit 1, Level 11. From cultural deposit containing dentate-stamped and incised Lapita pottery. Cal BC 1121 (1007) 911 at $1 \sigma$; cal BP 3070 (2956) 2860 at $1 \sigma$.

\section{Beta-21 789. Mussau Island}

$\mathbf{3 0 3 0} \pm \mathbf{8 0}$

Marine shell (Strombus, Turbo, Quidnit Level 17, Cultural Stratum IV. From deepest section of 
containing dentate-stamped Lapita pottery. Earliest occupation level of EKQ rock shelter. Cal BC 813 (771) 719 at $1 \sigma$; cal вP 2762 (2720) 2668 at $1 \sigma$.

\section{REFERENCES}

Allen, J, 1984, In search of the Lapita homeland: Jour Pacific History, v 19, p 186-201.

Ambrose, W R and Green, R C, 1972, First millennium BC transport of obsidian from New Britain to the Solomon Islands: Nature, v 237, p 31.

Ammerman, A J and Cavalli-Sforza, L L, 1984, The Neolithic transition and the genetics of populations in Europe: Princeton, Princeton Univ Press.

Anson, D, 1986, Lapita pottery of the Bismarck Archipelago and its affinities: Archaeology in Oceania, v 21, no. 3, p 157-165.

Bafmatuk, R, Egloff, B and Kaiku, R, 1980, Islanders: past and present: Hemisphere, v 25, p $77-81$.

Best, S, 1987, Long distance obsidian travel and possible implications for the settlement of Fiji: Archaeology in Oceania, v 22, p 27-31.

Clark J and Terrell, J, 1978, Archaeology in Oceania: Ann Rev Anthropol, v 7, p 293-319.

Diamond, J, 1977, Colonization cycles in man and beast: World Archaeology, v 8, p 249261.

Downie, J E and White, J P, 1979, Balof Shelter, New Ireland: report on a small excavation: Records Australian Mus, v 31, p 763-802.

Green, R C, 1979, Lapita, in Jennings, J, ed, The prehistory of Polynesia: Cambridge, Massachusetts, Harvard Univ Press, p 27-60.

Groube, L, Chappell, J, Muke, J and Price, D, 1986, A 40,000 year-old human occupation site at Huon Peninsula, Papua New Guinea: Nature, v 324, p 453-455.

Kirch, P V, 1982, Advances in Polynesian prehistory: three decades in review: Advances in World Archaeology, v 1, p 51-97.

1984, The evolution of the Polynesian chiefdoms: Cambridge, England, Cambridge Univ Press. 1987, Lapita and Oceanic cultural origins: excavations in the

Kirch, P V and Hunt, T L, in press, The spatial and temporal boundaries of the Lapita cultural complex, in Kirch, P V and Hunt, T L, eds, Lapita archaeology: A critical review: Burke Mus Research Rept, Seattle, Univ Washington.

Specht, J, Lilley, I and Normu, J, 1981, Radiocarbon dates from west New Britain, Papua New Guinea: Australian Archaeology, v 12, p 13-15.

Spriggs, M, 1984, The Lapita cultural complex: origins, distribution, contemporaries, and successors: Jour Pacific History, v 19, p 202-223.

Stuiver, $M$ and Becker, B, 1986, High-precision decadal calibration of the radiocarbon time scale, AD 1950-2500 BC, in Stuiver, $M$ and Kra, R S, eds, Internatl ${ }^{14} \mathrm{C}$ conf, 12th, Proc: Radiocarbon, v 28, no. 2B, p 863-910.

Stuiver, M, Pearson, G W and Braziunas, T, 1986, Radiocarbon age calibration of marine samples back to $9000 \mathrm{cal} \mathrm{BP}$, in Stuiver, M and Kra, R S, eds, Internatl ${ }^{14} \mathrm{C}$ conf, 12th, Proc: Radiocarbon, v 28, no. 2B, p 980-1021.

Stuiver, M and Polach, H A, 1977, Discussion: Reporting of ${ }^{14} \mathrm{C}$ data: Radiocarbon, v 19, no. 3, p 355-363.

Stuiver, $\mathrm{M}$ and Reimer, $\mathrm{P}$ J, 1986, A computer program for radiocarbon age calibration, in Stuiver, M and Kra, R S, eds, Internatl ${ }^{14} \mathrm{C}$ conf, 12 th, Proc: Radiocarbon, v 28, no 2B, p 1022-1030. 